\title{
Using Peroxymonosulfate-Ozone Advanced Oxidation For The Treated Wastewater Disinfection and Amoxicillin Micro-Pollutant Removal Simultaneously
}

Gagik Badalians Gholikandi

Shahid Beheshti University

Atefeh Mollazadeh

Shahid Beheshti University

Hamidreza Farimaniraad ( $\nabla$ hamidreza.fraad@gmail.com )

University of Tehran Faculty of Environment https://orcid.org/0000-0002-9359-843X

Hamidreza Masihi

Shahid Beheshti University

\section{Research Article}

Keywords: Disinfection, amoxicillin, advanced oxidation processes, peroxymonosulfate, persulfate-ozone, hydrogen peroxide, ozonation

Posted Date: October 13th, 2021

DOI: https://doi.org/10.21203/rs.3.rs-947027/v1

License: (c) (1) This work is licensed under a Creative Commons Attribution 4.0 International License.

Read Full License 


\section{Abstract}

Due to the recent efforts to improve the conventional disinfection methods efficiency of wastewater treatment plants effluent, in this study, the efficiency of the peroxymonosulfate-ozone $\left(\mathrm{PMS}+\mathrm{O}_{3}\right)$ advanced oxidation process in lab scale by the aim of disinfection and simultaneous removal of existing amoxicillin micro-pollutant under optimum operational condition was investigated for the first time. Furthermore, the results were compared with those obtained from the experiments conducted employing persulfate-ozone $\left(\mathrm{PS}+\mathrm{O}_{3}\right)$, hydrogen peroxide-ozone $\left(\mathrm{H}_{2} \mathrm{O}_{2}+\mathrm{O}_{3}\right)$, and ozonation $\left(\mathrm{O}_{3}\right)$ processes. For this purpose, the main parameters including the total coliforms, amoxicillin concentration, turbidity, chemical oxygen demand $(\mathrm{COD})$, biochemical oxygen demand $\left(\mathrm{BOD}_{5}\right)$, total nitrogen $(\mathrm{TN})$, electrical conductivity (EC), total dissolved solids (TDS), and total suspended solids (TSS) were considered. The test results show that under optimized operational conditions (retention time of 20 minutes, ozone dosage rate of $0.83 \mathrm{mmol} / \mathrm{L}$, and peroxymonosulfate concentration of $0.06 \mathrm{mmol}, 99.99 \%$ total coliforms (e.g., the number of total coliforms reached consistently less than 400 MPN in $100 \mathrm{ml}$ ) removal was reached by peroxymonosulfate-ozone advanced oxidation process. Also, amoxicillin concentration removal efficiency reached $90 \pm 2 \%$. In comparison, although the total coliforms reduction of $\mathrm{PS}+\mathrm{O}_{3}$ and $\mathrm{H}_{2} \mathrm{O}_{2}+\mathrm{O}_{3}$ methods in $30 \mathrm{~min}$ are approximately the same, the amoxicillin concentration removal efficiency is about $60-70 \%$. Due to the importance of ensuring effluent quality, the related removal efficiency of other considered parameters is also evaluated and presented. Eventually, the peroxymonosulfate-ozone method can be considered as a novel efficient approach for wastewater plants effluent disinfection and amoxicillin micro-pollutant removal simultaneously which is a novel approach.

\section{Introduction}

Although reusing the treated wastewater for urban and agricultural purposes has been considered as a part of integrated management of extractable water resources (US Environmental Protection Agency 2012; Ofori et al. 2021), the risk of pathogenic microorganisms discharges in the environment caused by inappropriate disinfected wastewater is one of the important concerns (Nasuhoglu et al. 2018). Therefore, the necessity of an efficient and ensured disinfection method for effluent of urban wastewater treatment plants is obvious (Malato et al. 2009).

In recent decades, pharmaceutical compounds residuals have been considered as the most important water contaminant due to their wide variety, high consumption, and stability in the environment (Homem and Santos 2011; Zaied et al. 2020). Among various pharmaceutical compounds, special attention has been given to the antibiotics due to their capability of producing antibiotical resistance in pathogen bacteria (Dimitrakopoulou et al. 2012; Zhou et al. 2021). More than $65 \%$ of consumed antibiotics in the world belong to the $\beta$-lactam group (Githinji et al. 2011). Amoxicillin is a broad-spectrum $\beta$-lactam antibiotic (with a chemical formula of $\mathrm{C}_{16} \mathrm{H}_{19} \mathrm{~N}_{3} \mathrm{O}_{5} \mathrm{~S}$ and a molecular weight of $365.4 \mathrm{~g} / \mathrm{mol}$ ) which belongs to penicillin group and is used systematically for the treatment of gastrointestinal bacterial infections in medicine and veterinary medicine (1998; Putra et al. 2009; Gao et al. 2020). In the previous 
studies, some methods were used to remove amoxicillin from water sources including: biological adsorption, advanced oxidation processes (AOPs), ion-exchange, coagulation/flocculation and combination of these methods (Kanakaraju et al. 2018; García-Menéndez et al. 2020; Rekhate and Srivastava 2020; Jalali et al. 2021). In the present study, removal of amoxicillin and disinfection of treated wastewater was conducted simultaneously using peroxymonosulfate-ozone advanced oxidation process.

Ozone is a powerful disinfectant and oxidant that is traditionally applied for water and wastewater treatment and higher disinfection efficiency compared to chlorination and ultraviolet (UV) radiation processes (Verma et al. 2015). In real experience, ozone is quite selective in the oxidation of organic compounds, and it has a very low reactivity with aromatics compounds (such as amoxicillin) (Oh et al. 2003). So, the advanced oxidation processes (AOPs) were used to dominate the ozone limitation.

Using advanced oxidation methods result in the production of hydroxyl radical $\left(\mathrm{OH}^{\circ}\right)\left(\mathrm{E}^{\circ}=2.8\right)$, (RodríguezChueca et al. 2017; Badalians Gholikandi et al. 2018) which has high reactivity and acts in a non-selective way (Gholikandi et al. 2017b). The results of studies of recent years have always indicated the capability of advanced oxidation methods in significant removal of the microbial community in the tested specimens (Badalians Gholikandi et al. 2014, 2018; Gholikandi et al. 2017a, b; Gholikandi and Kazemirad 2018; Masihi and Badalians Gholikandi 2018; Rasouli Sadabad and Badalians Gholikandi 2018). In the last decade, studies on advanced oxidation processes (AOPs) based on sulfate have increased (GuerraRodríguez et al. 2018). Sulfate radicals have high oxidation reactivity $(E=2.5-3.1 \mathrm{~V})$ (Cong et al. 2015; Wu et al. 2019) and acceptable performance at a wide range of pH values of 4-9 (Ren et al. 2015). They are often obtained by activating peroxymonosulfate ( $\mathrm{PMS} \mathrm{HSO}_{5}{ }^{-}$) and persulfate $\left(\mathrm{PS}: \mathrm{S}_{2} \mathrm{O}_{8}{ }^{2-}\right.$ ) using ozone, heat, UV, ultrasound, or heterogeneous and homogenous catalysts (Alkhuraiji et al. 2017; RodríguezChueca et al. 2017; Wacławek et al. 2017; Wang and Wang 2018a, b; Latif et al. 2019). Studies have been conducted on sulfate-based AOP methods for deactivation of pathogenic Escherichia coli (Wordofa et al. 2017; Xia et al. 2018). Ozone/hydrogen peroxide (O3/H2O2) is also used in water treatment facilities to remove many organic micropollutants. The $03 / \mathrm{H} 202$ process, also known as peroxone $\mathrm{AOP}$, uses a radical chain system to decompose ozone, which is activated by the hydroperoxide anion $\mathrm{HO}_{2}^{-}$(Rekhate and Srivastava 2020). Badalians Gholikandi et al. (2018) conducted a comparative study on sludge stabilization using $\mathrm{H}_{2} \mathrm{O}_{2}+\mathrm{O}_{3}, \mathrm{PMS}+\mathrm{O}_{3}$, $\mathrm{PS}+\mathrm{O}_{3}$, and $\mathrm{O}_{3}$ methods and found that $\mathrm{PMS}+\mathrm{O}_{3}$ had a better performance than the other methods (Badalians Gholikandi et al. 2018).

In this study, the PMS $+\mathrm{O}_{3}$ advanced oxidation process which is able to produce sulfate and hydroxyl radicals simultaneously was employed to remove total coliforms and amoxicillin micropollutant from the urban wastewater treatment plant effluent. Also, the obtained results were compared with ozonation, hydrogen peroxide-ozone, and persulfate-ozone methods capability. The comparison is made in the first instance based on the two main parameters, e.g., total coliforms and amoxicillin removal. Further, the main parameters for removal efficiency under optimized operational conditions as the main considered parameters relating to wastewater treatment plants effluent quality were analyzed including the total 
coliforms, amoxicillin concentration, turbidity, chemical oxygen demand (COD), biochemical oxygen demand $\left(\mathrm{BOD}_{5}\right)$, total nitrogen (TN), EC, total dissolved solids (TDS), and total suspended solids (TSS).

\section{Materials And Methods \\ 2.1. Materials}

\subsubsection{Treated wastewater Sample (before disinfection)}

The treated wastewater samples (wastewater treatment plant effluent before chlorination) used in this experiment were taken daily from the activated sludge urban wastewater treatment plant which is located in the north east Tehran. Characteristics of the treated wastewater samples are listed in Table 1.

Table 1 The characteristics of the treated wastewater samples.

\begin{tabular}{|lll}
\hline Parameter & Unit & Value \\
\hline $\mathrm{pH}$ & - & $7.1 \pm 0.2$ \\
\hline Total coliform & MPN in 100 milliliter & $(2.1 \pm 0.3) \times 10^{6}$ \\
\hline Turbidity & $\mathrm{NTU}$ & $10 \pm 3$ \\
\hline Chemical oxygen demand (COD) & $\mathrm{mg} / \mathrm{L}$ & $34 \pm 5$ \\
\hline Biological oxygen demand (BOD $\left.{ }_{5}\right)$ & $\mathrm{mg} / \mathrm{L}$ & $20 \pm 5$ \\
\hline Total Nitrogen (TN) & $\mathrm{mg} / \mathrm{L}$ & $40 \pm 5$ \\
\hline Total phosphorus (TP) & $\mathrm{mg} / \mathrm{L}$ & $10 \pm 2$ \\
\hline Temperature & ${ }^{\circ} \mathrm{C}$ & $18 \pm 1$ \\
\hline Electrical conductivity(EC) & $\mu S / \mathrm{cm}$ & $715 \pm 20$ \\
\hline Total dissolved solid (TDS) & $\mathrm{mg} / \mathrm{L}$ & $453 \pm 50$ \\
\hline Total suspended solids (TSS) & $\mathrm{mg} / \mathrm{L}$ & $18 \pm 5$ \\
\hline
\end{tabular}

\subsubsection{Test Setup}

A cylindrical reactor in a laboratory scale with a diameter of $3 \mathrm{~cm}$ and a height of $40 \mathrm{~cm}$ was used to conduct the studies (Fig. 1). The ozone generator (Arda Company, Ozoneplus series-COG high voltage) with a capacity of $500 \mathrm{mg} / \mathrm{h}$ was employed to produce ozone. In addition, two gas washing bottles were attached in series to test the reactor's output ozone.

\subsubsection{Used materials}


Potassium peroxymonosulfate, potassium persulfate, and hydrogen peroxide (35\%) purchased from Merck Company and amoxicillin made by Sigma-Aldrich Company were utilized in this experiment.

\subsection{Experimental procedure}

In order to measure the Total Suspended Solids (TSS) concentration, Total Dissolved Solids (TDS) concentration, Chemical Oxygen Demand (COD), Biological Oxygen Demand $\left(\mathrm{BOD}_{5}\right)$, Total Nitrogen (TN) concentration, Total Phosphorus (TP) concentration, ozone concentration, and total coliform, the following methods were used respectively: 2540D, 2540C, 5220D, 5210B, 4500N-C, 4500B-C, 2350E, and 9221B standard methods (APHA 1992). Also, HANNA pH meter-211, OSK 14821 conductivity meter, and Lovibond turbicheck devices were used to measure $\mathrm{pH}$, electrical conductivity, and turbidity, respectively. In order to measure the concentration of amoxicillin, the Jenway 6315 UV-spectrophotometer at a wavelength of $228.3 \mathrm{~nm}$ was used (Weng et al. 2013). The experiment was conducted in the reactor shown in Fig. 1. The initial concentration of amoxicillin was considered to be $36.5 \mathrm{mg} / \mathrm{L}$ because the concentration of more than $36.5 \mathrm{mg} / \mathrm{L}$ leads to minimal inhibitory for the test organisms (Moreira et al. 2015). The concentration of amoxicillin was zero at effluent (treated wastewater sample), and amoxicillin was added synthetically to the samples.

\section{Results}

\subsection{Reduction of total coliform and amoxicillin}

In the present study, the effect of using $\mathrm{H}_{2} \mathrm{O}_{2}+\mathrm{O}_{3}, \mathrm{PMS}+\mathrm{O}_{3}, \mathrm{PS}+\mathrm{O}_{3}$, and $\mathrm{O}_{3}$ on the removal of total coliform has been studied, and the optimum operational conditions have been determined. In these processes, radicals of hydroxyl or sulfate (or both of them) act as oxidation agents. Therefore, increasing the production of these agents leads to an increase in the removal of total coliform. An allowable limit for the total coliforms, e.g., $400 \mathrm{MPN}$ in $100 \mathrm{ml}$, was considered as the criterion for successful disinfection of wastewater (in this way, the allowable limit criterion for the presence of fecal coliform according to the wastewater reuse standards for agricultural purposes is met, too). Regarding the importance of the removal of specific contaminants with a pharmaceutical origin, the amoxicillin removal as one of the commonly residual drugs in wastewater was also investigated. Also, the theoretically required ozone dosage to disinfect secondary clarifier output is 0.083 to $0.2 \mathrm{mmol} / \mathrm{L}$ (Tchobanoglous et al. 1990) that in this study the dosage of ozone was considered to be $0.083 \mathrm{mmol} / \mathrm{L}$ which is the least dosage needed for ozonation according to Metcalf and Eddy (Metcalf and Eddy 2003).

\subsubsection{Ozone and hydrogen peroxide $\left(\mathrm{H}_{2} \mathrm{O}_{2}+\mathrm{O}_{3}\right)$}

As shown in Fig. 2, in the absence of $\mathrm{H}_{2} \mathrm{O}_{2}$, when only the ozone participates in the reaction, the amount of the log (MPN) decreases after a reaction time of 30 min from 6.3 to 3.7, e.g., the number of coliforms becomes from 2100000 to $5300 \mathrm{MPN} / 100 \mathrm{ml}$. In this method, the production of hydroxyl radical is occurred based on Reaction 1 (Munter 2001). After starting the hydrogen peroxide addition, when its 
dosage reaches $0.35 \mathrm{mmol} / \mathrm{L}$, the amount of $\log (\mathrm{MPN})$ decreases after a reaction time of $30 \mathrm{~min}$ from $6.3(2100000)$ to 2.8 (624). In the same reaction time, by increasing the dosage of hydrogen peroxide to $0.7 \mathrm{mmol} / \mathrm{L}$ and then $1.05 \mathrm{mmol} / \mathrm{L}$, the amount of $\log (\mathrm{MPN})$ reduces from 6.3 (2100000) to 2.27 (185) and 1.81 (65), respectively. Based on the obtained results, by increasing the dose of $\mathrm{H}_{2} \mathrm{O}_{2}$, the amount of total coliform removal, increases, too. The highest amount of removal is for $\mathrm{H}_{2} \mathrm{O}_{2}$ dosage of $1.05 \mathrm{mmol} / \mathrm{L}$ in a reaction time of 30 minutes. However, the optimum operating conditions of the reactor to achieve the allowable maximum coliforms number of 400 in $100 \mathrm{ml}$ can be obtained by $\mathrm{H}_{2} \mathrm{O}_{2}$ dosage of $0.7 \mathrm{mmol} / \mathrm{L}$ and a reaction time of $20 \mathrm{~min}$, resulting in $\log (\mathrm{MPN})=2.57$ (e.g., $371 \mathrm{MPN} / 100 \mathrm{ml}<400)$.

$$
\mathrm{H}_{2} \mathrm{O}_{2}+2 \mathrm{O}_{3} \rightarrow 2 \mathrm{OH}^{\circ}+3 \mathrm{O}_{2}(1)
$$

\subsubsection{Ozone and peroxymonosulfate $\left(P M S+\mathrm{O}_{3}\right)$}

As shown in Fig. 3, in the absence of PMS, when only ozone participates in the reaction, the amount of the $\log ($ MPN) after a reaction time of 30 minutes, reduces from 6.3 (2100000) to 3.7 (5300). In this method, the production of hydroxyl and sulfate radicals is carried out based on Reactions 2-9 (Yang et al. 2015, 2016; Badalians Gholikandi et al. 2018). After starting the dosing of peroxymonosulfate, while its concentration reaches $0.03 \mathrm{mmol} / \mathrm{L}$, the amount of $\log (\mathrm{MPN})$ after a reaction time of $30 \mathrm{~min}$ reduces from $6.3(2100000)$ to 3.12 (1324). In the same reaction time, by increasing the dosage of peroxymonosulfate to $0.06 \mathrm{mmol} / \mathrm{L}$ and then $0.09 \mathrm{mmol} / \mathrm{L}$, the amount of $\log (\mathrm{MPN})$ reduces from 6.3 (2100000) to 2.16 (145) and 1.98 (95), respectively. Based on the obtained results, it can be said that by increasing the dose of PMS, the amount of total coliform removal, increases, too. The highest removal efficiency is by a PMS dosage of $0.09 \mathrm{mmol} / \mathrm{L}$ in a reaction time of $30 \mathrm{~min}$. It should be noted, however, that the optimum operational conditions for the reactor to achieve the allowable limit of maximum 400 coliforms in $100 \mathrm{ml}$ in a PMS dosage of $0.06 \mathrm{mmol} / \mathrm{L}$, can be obtained by achieving log (MPN) $=2.16$ (e.g.145 MPN/100ml) in a reaction time of 20 minutes.

$$
\begin{aligned}
& \mathrm{O}_{3}+\mathrm{OH}^{-} \rightarrow \mathrm{HO}_{2}^{-}+\mathrm{O}_{2}(2) \\
& \mathrm{O}_{3}+\mathrm{HO}_{2}{ }^{-} \rightarrow \mathrm{OH}_{2}{ }^{\circ}+\mathrm{O}_{3}{ }^{-\circ}(3) \\
& \mathrm{O}_{3}{ }^{-}+\mathrm{H}_{2} \mathrm{O} \rightarrow \mathrm{OH}^{\circ}+\mathrm{O}_{2}+\mathrm{OH}^{-} \\
& \mathrm{KSO}_{5} \leftrightarrow \mathrm{K}^{+}+\mathrm{HSO}_{5}{ }^{-}(5) \\
& \mathrm{HSO}_{5}{ }^{-} \rightarrow \mathrm{H}^{+}+\mathrm{SO}_{5}{ }^{2-}(6) \\
& \mathrm{SO}_{5}{ }^{2-}+\mathrm{O}_{3} \rightarrow \mathrm{SO}_{5}{ }^{-\circ}+\mathrm{O}_{3}{ }^{-}(7) \\
& \mathrm{SO}_{5}{ }^{-}+\mathrm{O}_{3} \rightarrow \mathrm{SO}_{4}{ }^{-}+2 \mathrm{O}_{2}(8)
\end{aligned}
$$


$2 \mathrm{SO}_{5}^{-{ }^{\circ}} \rightarrow 2 \mathrm{SO}_{4}^{-0^{\circ}}+\mathrm{O}_{2}(9)$

\subsubsection{Ozone and persulfate (PS $+\mathrm{O}_{3}$ )}

As shown in Fig. 4, when the dosage of PS is zero, the amount of the $\log (\mathrm{MPN})$ reduces after a reaction time of $30 \mathrm{~min}$ from 6.3 (2100000) to 3.7 (5300). In this method, the production of sulfate radical is carried out according to the reaction 10 (Reisner, 2016). When the injection of persulfate is started, and its dosage reaches $1 \mathrm{mmol} / \mathrm{L}$, the amount of $\log (\mathrm{MPN})$ decreases after $30 \mathrm{~min}$ from 6.3 (2100000) to 3.36 (2298). In the same reaction time, by increasing the dosage of persulfate to $2 \mathrm{mmol} / \mathrm{L}$ and then 3 $\mathrm{mmol} / \mathrm{L}$, the amount of $\log (\mathrm{MPN})$ reduces from 6.3 (2100000) to 3.04 (1105) and 2.64 (435), respectively. Based on the obtained results, it can be said that by increasing the dose of PS, the amount of total coliform removal, increases, too. The highest amount of removal is for a PS dosage of $3 \mathrm{mmol} / \mathrm{L}$ in a reaction time of 30 minutes.

$\mathrm{S}_{2} \mathrm{O}_{8}{ }^{2-}+\mathrm{OH}^{\circ} \rightarrow \mathrm{SO}_{4}{ }^{-\circ}+\mathrm{SO}_{4}{ }^{-\circ}+1 / 2 \mathrm{O}_{2}+\mathrm{H}^{+}(10)$

\subsubsection{Amoxicillin removal}

Amoxicillin was not present in treated wastewater. The concentration of $36.5 \mathrm{mg} / \mathrm{L}$ of amoxicillin was added synthetically to the samples. Under optimum conditions of methods, their ability to remove amoxicillin was studied. PMS + 03, $\mathrm{H} 2 \mathrm{O} 2+03$, and PS + 03 methods reduced amoxicillin levels by 90 , 62.5 and $67.5 \%$, respectively, in addition, to reduce total coliforms to the standard limit. Also, $\mathrm{O}_{3}$ alone reduced the amount of amoxicillin by $53.6 \%$. As the results showed, the PMS $+\mathrm{O}_{3}$ method had the best performance and had the ability to disinfect and reduce the micropollutant simultaneously. As it can be seen from the results, high concentrations of $\mathrm{H}_{2} \mathrm{O}_{2}$, PS and PMS did not further increase the efficiency of the process which can be due to the fact that the excessive dose of oxidants could not act as scavenger of ${ }^{~} \mathrm{OH}$ and $\mathrm{SO}_{4}^{-}$and also it can facilitate the abundant $\mathrm{SO}_{4}^{-}$to transform into the useless ions which can cause a decrease in removal of amoxicillin.

\subsection{Other Parameters analysis}

The effect of using $\mathrm{H}_{2} \mathrm{O}_{2}+\mathrm{O}_{3}$, $\mathrm{PMS}+\mathrm{O}_{3}$, and $\mathrm{PS}+\mathrm{O}_{3}$ on the qualitative parameters of wastewater discharge including turbidity, $\mathrm{COD}, \mathrm{BOD}_{5}, \mathrm{TN}, \mathrm{TP}, \mathrm{EC}$, TSS, and TDS has been investigated under optimum conditions of disinfection, the results of which are shown in Tables 2 and 3.

Table 2 The effect of methods on characteristics of the treated wastewater sample 


\begin{tabular}{|c|c|c|c|c|c|c|c|}
\hline \multicolumn{2}{|l|}{ Parameter } & \multirow[t]{2}{*}{ Unit } & \multirow[t]{2}{*}{ Effluent } & \multicolumn{4}{|c|}{ Methods } \\
\hline & & & & $\begin{array}{l}\text { PMS } \\
+\mathrm{O}_{3}\end{array}$ & $\begin{array}{l}\mathrm{PS}+ \\
\mathrm{O}_{3}\end{array}$ & $\begin{array}{l}\mathrm{H}_{2} \mathrm{O}_{2} \\
+\mathrm{O}_{3}\end{array}$ & $\mathrm{O}_{3}$ \\
\hline \multirow{2}{*}{$\begin{array}{l}\text { optimal } \\
\text { Condition }\end{array}$} & Time & $\min$ & - & 20 & 30 & 20 & 30 \\
\hline & $\begin{array}{l}\text { Dosage of the } \\
\text { PMS,PS, } \mathrm{H}_{2} \mathrm{O}_{2} \\
\text { and } \mathrm{O}_{3}\end{array}$ & $\mathrm{mmol} / \mathrm{L}$ & - & 0.06 & 3 & 0.7 & 0.083 \\
\hline \multicolumn{2}{|l|}{ Turbidity } & NTU & 7.39 & 2.78 & 2.89 & 3.43 & 4.21 \\
\hline \multicolumn{2}{|c|}{ Chemical oxygen demand (COD) } & $\mathrm{mg} / \mathrm{L}$ & 36 & 23 & 34 & 16 & 35 \\
\hline \multicolumn{2}{|c|}{ Biological oxygen demand $\left(\mathrm{BOD}_{5}\right)$} & $\mathrm{mg} / \mathrm{L}$ & 21 & 16 & 19 & 13 & 19 \\
\hline \multicolumn{2}{|c|}{ Total nitrogen(TN) } & $\mathrm{mg} / \mathrm{L}$ & 38.67 & 38.67 & 38.67 & 38.67 & 38.67 \\
\hline \multicolumn{2}{|c|}{$\begin{array}{l}\text { Total } \\
\text { phosphorus(TP) }\end{array}$} & $\mathrm{mg} / \mathrm{L}$ & 10.5 & 10.5 & 10.5 & 10.5 & 10.5 \\
\hline \multicolumn{2}{|c|}{ Temperature } & ${ }^{\circ} \mathrm{C}$ & 17.8 & 17.6 & 17.6 & 17.6 & 17.8 \\
\hline \multicolumn{2}{|c|}{$\begin{array}{l}\text { Electrical } \\
\text { conductivity(EC) }\end{array}$} & $\mu S / \mathrm{cm}$ & 709 & 878 & 1695 & 692 & 712 \\
\hline \multicolumn{2}{|c|}{ Total dissolved solids (TDS) } & $\mathrm{mg} / \mathrm{L}$ & 471 & 569 & 1154 & 470 & 472 \\
\hline \multicolumn{2}{|c|}{ Total suspended solids (TSS) } & $\mathrm{mg} / \mathrm{L}$ & 15.6 & 3.8 & 4.2 & 5.1 & 10.2 \\
\hline
\end{tabular}

Table 3 The removal efficiency of methods on turbidity, COD, BOD, and TSS of the treated wastewater sample

\begin{tabular}{|c|c|c|c|c|c|c|}
\hline \multicolumn{2}{|l|}{ Parameter } & \multirow[t]{2}{*}{ Unit } & \multicolumn{4}{|c|}{ Methods } \\
\hline & & & $\begin{array}{l}\text { PMS + } \\
\mathrm{O}_{3}\end{array}$ & $\begin{array}{l}\mathrm{PS}+ \\
\mathrm{O}_{3}\end{array}$ & $\begin{array}{l}\mathrm{H}_{2} \mathrm{O}_{2}+ \\
\mathrm{O}_{3}\end{array}$ & $\mathrm{O}_{3}$ \\
\hline \multirow{2}{*}{$\begin{array}{l}\text { optimal } \\
\text { Condition }\end{array}$} & Time & $\min$ & 20 & 30 & 20 & 30 \\
\hline & $\begin{array}{l}\text { Dosage of the PMS,PS and } \\
\mathrm{H}_{2} \mathrm{O}_{2}\end{array}$ & $\mathrm{mmol} / \mathrm{L}$ & 0.06 & 3 & 0.7 & 0.083 \\
\hline \multicolumn{2}{|c|}{ Turbidity removal } & $\%$ & 62.4 & 60.9 & 53.6 & 43 \\
\hline \multicolumn{2}{|c|}{ COD removal } & $\%$ & 36 & 5.56 & 55.56 & 2.7 \\
\hline \multicolumn{2}{|c|}{ BOD removal } & $\%$ & 23.8 & 9.5 & 38.1 & 9.5 \\
\hline \multicolumn{2}{|c|}{ TSS removal } & $\%$ & 75.6 & 73.1 & 67.3 & 34.6 \\
\hline
\end{tabular}


Based on the results, a comparison between investigated methods under optimum operational conditions at a temperature of $17.6^{\circ} \mathrm{C}$ and constant ozone dosage rate of $0.083 \mathrm{mmol} / \mathrm{L}$ shows the following removal efficiencies: turbidity removal of $\mathrm{PMS}+\mathrm{O}_{3}(=62 \%), \mathrm{PS}+\mathrm{O}_{3}(=61 \%)$, and $\mathrm{H}_{2} \mathrm{O}_{2}+\mathrm{O}_{3}(=54 \%)$; $\mathrm{COD}$ removal of $\mathrm{H}_{2} \mathrm{O}_{2}+\mathrm{O}_{3}(=56 \%), \mathrm{PMS}+\mathrm{O}_{3}(=36 \%)$, and $\mathrm{PS}+\mathrm{O}_{3}(=6 \%) ; \mathrm{BOD}_{5}$ removal of $\mathrm{H}_{2} \mathrm{O}_{2}+\mathrm{O}_{3}(=38 \%)$, $\mathrm{PMS}+\mathrm{O}_{3}(=24 \%)$, and $\mathrm{PS}+\mathrm{O}_{3}(=10 \%)$; TSS removal of PMS $+\mathrm{O}_{3}(=76 \%), \mathrm{PS}+\mathrm{O}_{3}(=74 \%)$, and $\mathrm{H}_{2} \mathrm{O}_{2}+\mathrm{O}_{3}$ $(=67 \%)$, and amoxicillin removal of $\mathrm{PMS}+\mathrm{O}_{3}(=90 \pm 5 \%), \mathrm{PS}+\mathrm{O}_{3}(=67 \pm 5 \%)$, and $\mathrm{H}_{2} \mathrm{O}_{2}+\mathrm{O}_{3}(=62 \pm 5 \%)$. The EC value at the temperature of $17.6^{\circ} \mathrm{C}$ was $\mathrm{H} 2 \mathrm{O} 2+03, \mathrm{PMS}+03$, and $\mathrm{PS}+03$, respectively as the lowest values. TDS for the raw sample was measured $471 \mathrm{mg} / \mathrm{L}$, whereas it reached $569 \mathrm{mg} / \mathrm{L}, 1154$ $\mathrm{mg} / \mathrm{L}$, and $470 \mathrm{mg} / \mathrm{L}$ using the PMS $+\mathrm{O}_{3}, \mathrm{PS}+\mathrm{O}_{3}$, and $\mathrm{H}_{2} \mathrm{O}_{2}+\mathrm{O}_{3}$ methods, respectively. None of the methods had an effect on the TN and TP concentrations.

\section{Overall Discussion}

In this study, treated wastewater effluent disinfection and residual amoxicillin removal employing PMS + $\mathrm{O}_{3}, \mathrm{PS}+\mathrm{O}_{3}, \mathrm{H}_{2} \mathrm{O}_{2}+\mathrm{O}_{3}$, and $\mathrm{O}_{3}$ alone with the aim of secure availability for reuse purposes were investigated. Under the same operation conditions, $\mathrm{O}_{3}$ alone is incapable of achieving coliforms reduction requirement in this regard. The $\mathrm{PMS}+\mathrm{O}_{3}$ process is an appropriate method to reach efficient disinfection of wastewater treatment plants effluent and to achieve an effective residual amoxicillin removal simultaneously. In comparison to other investigated methods, higher efficiency in turbidity and TSS removal is achievable. Regarding other parameters, e.g., $\mathrm{COD}$ and $\mathrm{BOD}_{5}$, the removal efficiency is still considerable. Summing up the results, it can be concluded that this method is very useful for effluent of a pharmaceutical sewage treatment plant. Although this method is incapable of removing existing TN and TP concentrations, adverse byproducts generation in reaction with these parameters is not feasible.

\section{Conclusion}

Special attention has been given to the reliable usage of urban sewage treatment plants' wastewater in agriculture and greenspace irrigation in recent decades. Especially optimum disinfection of wastewater discharge is one of the main prerequisites of reuse. In this study, a new approach for improving the performance of ozone disinfection method by simultaneous usage of ozone compared to ozone/persulfate and ozone/hydrogen peroxide has been studied. The focus of recent researches has been on the presence of micropollutants in sewage treatment plants' wastewater, including the residue of pharmaceutical materials, therefore in this research the possible amount of amoxicillin removal under optimum conditions of the mentioned methods was evaluated. Although the obtained results indicate an almost identical performance of disinfection for the studied methods, the amount of amoxicillin removal in ozone/peroxymonosulfate method was higher than the other ones. It was also found that this method can remove amoxicillin and similar pharmaceutical materials in addition to wastewater disinfection. Therefore, the ozone/peroxymonosulfate method is proposed as a new novel approach for amoxicillin removal. Complementary study on the possible byproducts of the process on a semi-industrial scale is essential in follow-up to this research. 


\section{Abbreviations}

\begin{tabular}{|lll|}
\hline${ }^{\circ} \mathrm{C}$ & Centigrade \\
$\mathrm{g}$ & gram \\
$\mathrm{h}$ & hour \\
\hline $\mathrm{L}$ & Liter \\
\hline$\mu S$ & microsiemens \\
$\mathrm{mg}$ & milligram \\
$\mathrm{ml}$ & milliliter \\
$\mathrm{mm}$ & millimeter \\
$\mathrm{mmol}$ & millimole \\
\hline $\mathrm{min}$ & minute \\
\hline $\mathrm{MPN}$ & Most Probable Number \\
\hline $\mathrm{nm}$ & nanometer \\
\hline $\mathrm{NTU}$ & Nephelometric Turbidity Unit \\
\hline $\mathrm{V}$ & Volt \\
\hline
\end{tabular}

Declarations

\section{Ethics approval and consent to participate:}

Not applicable

\section{Consent for publication:}

Not applicable

\section{Availability of data and materials:}

The datasets used and/or analysed during the current study are available from the corresponding author on reasonable request.

\section{Competing interests:}

The authors declare that they have no competing interests 


\section{Funding:}

No funding was received for conducting this study.

\section{Authors' contributions:}

All authors contributed to the study conception and design. Material preparation, data collection and analysis were performed by Atefeh Mollazadeh, Hamidreza Masihi and Gagik Badalians Gholikandi. The first draft of the manuscript was written by Hamidreza Farimaniraad and Atefeh Mollazadeh. All authors commented on previous versions of the manuscript. All authors read and approved the final manuscript.

\section{Conflicts of interests:}

The authors have no conflicts of interest to declare that are relevant to the content of this article.

\section{References}

1. HPLC Methods for Pharmaceutical Analysis. Instrum Sci Technol 26:. https://doi.org/10.1080/10739149808001911

2. Alkhuraiji TS, Boukari SOB, AlfadhI FS (2017) Gamma irradiation-induced complete degradation and mineralization of phenol in aqueous solution: Effects of reagent. J Hazard Mater 328:. https://doi.org/10.1016/j.jhazmat.2017.01.004

3. APHA (1992) American Public Health Association Method 3112: Standard Methods for the Examination of Water and Wastewater. Methods Exam water wastewater 552

4. Badalians Gholikandi G, Masihi H, Azimipour M et al (2014) Optimizing stabilization of wasteactivated sludge using Fered-Fenton process and artificial neural network modeling (KSOFM, MLP). Environ Sci Pollut Res 21:. https://doi.org/10.1007/s11356-014-2633-1

5. Badalians Gholikandi G, Zakizadeh N, Masihi H (2018) Application of peroxymonosulfate-ozone advanced oxidation process for simultaneous waste-activated sludge stabilization and dewatering purposes: A comparative study. J Environ Manage 206:.

https://doi.org/10.1016/j.jenvman.2017.10.070

6. Cong J, Wen G, Huang T et al (2015) Study on enhanced ozonation degradation of parachlorobenzoic acid by peroxymonosulfate in aqueous solution. Chem Eng J 264:. https://doi.org/10.1016/j.cej.2014.11.086

7. Dimitrakopoulou D, Rethemiotaki I, Frontistis $Z$ et al (2012) Degradation, mineralization and antibiotic inactivation of amoxicillin by UV-A/TiO 2 photocatalysis. J Environ Manage 98:. https://doi.org/10.1016/j.jenvman.2012.01.010 
8. Gao B, Wang J, Dou M et al (2020) Enhanced photocatalytic removal of amoxicillin with $\mathrm{Ag} / \mathrm{TiO} 2 /$ mesoporous g-C3N4 under visible light: property and mechanistic studies. Environ Sci Pollut Res 27:7025-7039. https://doi.org/10.1007/s11356-019-07112-8

9. García-Menéndez L, Leyva-Díaz JC, Díaz E, Ordóñez S (2020) Biological absorption as main route for amoxicillin reduction and heterotrophic kinetic modeling in a "NIPHO" bioreactor. J Environ Chem Eng. https://doi.org/10.1016/j.jece.2020.104775

10. Gholikandi GB, Kazemirad K (2018) Application of electrochemical peroxidation (ECP) process for waste-activated sludge stabilization and system optimization using response surface methodology (RSM). Water Sci Technol 77:. https://doi.org/10.2166/wst.2018.066

11. Gholikandi GB, Sadabad HR, Karami S, Masihi H (2017a) Heavy metal ions removal from wasteactivated sludge by fered-fenton electrochemical advanced oxidation process (EAOP) with the aim of agricultural land application. Desalin Water Treat 93:. https://doi.org/10.5004/dwt.2017.21224

12. Gholikandi GB, Zakizadeh N, Karami S, Masihi H (2017b) Employing fered-fenton advanced oxidation process for waste-activated sludge stabilization and reuse. Desalin Water Treat 93:. https://doi.org/10.5004/dwt.2017.21431

13. Githinji LJM, Musey MK, Ankumah RO (2011) Evaluation of the fate of ciprofloxacin and amoxicillin in domestic wastewater. Water Air Soil Pollut 219:. https://doi.org/10.1007/s11270-010-0697-1

14. Guerra-Rodríguez S, Rodríguez E, Singh DN, Rodríguez-Chueca J (2018) Assessment of sulfate radical-based advanced oxidation processes for water and wastewater treatment: A review. Water (Switzerland) 10

15. Homem V, Santos L (2011) Degradation and removal methods of antibiotics from aqueous matrices A review. J. Environ. Manage. 92

16. Jalali S, Ardjmand M, Ramavandi B, Nosratinia F (2021) Removal of amoxicillin from wastewater in the presence of $\mathrm{H} 2 \mathrm{O} 2$ using modified zeolite $\mathrm{Y}-\mathrm{MgO}$ catalyst: An optimization study. Chemosphere 274:. https://doi.org/10.1016/j.chemosphere.2021.129844

17. Kanakaraju D, Glass BD, Oelgemöller M (2018) Advanced oxidation process-mediated removal of pharmaceuticals from water: A review. J. Environ. Manage. 219

18. Latif A, Kai S, Si Y (2019) Catalytic degradation of organic pollutants in Fe(III)/peroxymonosulfate (PMS) system: performance, influencing factors, and pathway. Environ Sci Pollut Res 26:3641036422. https://doi.org/10.1007/s11356-019-06657-y

19. Malato S, Fernández-lbáñez P, Maldonado MI et al (2009) Decontamination and disinfection of water by solar photocatalysis: Recent overview and trends. Catal. Today 147

20. Masihi H, Badalians Gholikandi G (2018) Employing Electrochemical-Fenton process for conditioning and dewatering of anaerobically digested sludge: A novel approach. Water Res 144:. https://doi.org/10.1016/j.watres.2018.07.054

21. Metcalf W, Eddy C (2003) Metcalf and Eddy Wastewater Engineering: Treatment and Reuse. Wastewater Eng Treat Reuse McGraw Hill New York, NY 
22. Moreira NFF, Orge CA, Ribeiro AR et al (2015) Fast mineralization and detoxification of amoxicillin and diclofenac by photocatalytic ozonation and application to an urban wastewater. Water Res 87:. https://doi.org/10.1016/j.watres.2015.08.059

23. Munter R (2001) Advanced Oxidation Processes - Current Status and Prospect. Proc Est Acad Sci Chem 50:. https://doi.org/10.1002/9780470561331.ch18

24. Nasuhoglu D, Isazadeh $S$, Westlund $P$ et al (2018) Chemical, microbial and toxicological assessment of wastewater treatment plant effluents during disinfection by ozonation. Chem Eng J 346:. https://doi.org/10.1016/j.cej.2018.04.037

25. Ofori S, Puškáčová A, Růžičková I, Wanner J (2021) Treated wastewater reuse for irrigation: Pros and cons. Sci. Total Environ. 760

26. Oh BS, Park SJ, Lee HG et al (2003) Application of Ozone/UV Process for the Reclamation of Sewage Treatment Plant Effluent. J Water Environ Technol 1:. https://doi.org/10.2965/jwet.2003.141

27. Putra EK, Pranowo R, Sunarso J et al (2009) Performance of activated carbon and bentonite for adsorption of amoxicillin from wastewater: Mechanisms, isotherms and kinetics. Water Res 43:. https://doi.org/10.1016/j.watres.2009.02.039

28. Rasouli Sadabad H, Badalians Gholikandi G (2018) Simultaneous effective sludge stabilization and direct electricity generation by merging microbial fuel cell (MFC) and Fered-Fenton reactor: An experimental study. Biomass Bioenerg 119:. https://doi.org/10.1016/j.biombioe.2018.09.028

29. Rekhate CV, Srivastava JK (2020) Recent advances in ozone-based advanced oxidation processes for treatment of wastewater- A review. Chem Eng J Adv 3:100031. https://doi.org/https://doi.org/10.1016/j.ceja.2020.100031

30. Ren W, Zhou Z, Zhu Y et al (2015) Effect of sulfate radical oxidation on disintegration of waste activated sludge. Int Biodeterior Biodegrad 104:. https://doi.org/10.1016/j.ibiod.2015.07.008

31. Rodríguez-Chueca J, Silva T, Fernandes JR et al (2017) Inactivation of pathogenic microorganisms in freshwater using HSO5-/UV-A LED and HSO5-/Mn+/UV-A LED oxidation processes. Water Res 123:. https://doi.org/10.1016/j.watres.2017.06.021

32. Tchobanoglous G, Burton FL, Stensel HD (1990) Metcalf \& Eddy-Wastewater Engineering - Treatment and Reuse (4th edition). Bull. Int. Union Tuberc. Lung Dis. 65

33. US Environmental Protection Agency (2012) Guidelines for Water Reuse. Development 26

34. Verma K, Gupta KD, Gupta AB (2015) A review on sewage disinfection and need of improvement. Desalin. Water Treat. 56

35. Wacławek S, Lutze HV, Grübel K et al (2017) Chemistry of persulfates in water and wastewater treatment: A review. Chem. Eng. J. 330

36. Wang J, Wang S (2018a) Activation of persulfate (PS) and peroxymonosulfate (PMS) and application for the degradation of emerging contaminants. Chem. Eng. J. 334

37. Wang S, Wang J (2018b) Degradation of carbamazepine by radiation-induced activation of peroxymonosulfate. Chem Eng J 336:. https://doi.org/10.1016/j.cej.2017.12.068 
38. Weng X, Lin S, Zhong Y, Chen Z (2013) Chitosan stabilized bimetallic Fe/Ni nanoparticles used to remove mixed contaminants-amoxicillin and Cd (II) from aqueous solutions. Chem Eng J 229:. https://doi.org/10.1016/j.cej.2013.05.096

39. Wordofa DN, Walker SL, Liu H (2017) Sulfate Radical-Induced Disinfection of Pathogenic Escherichia coli 0157:H7 via Iron-Activated Persulfate. Environ Sci Technol Lett 4:. https://doi.org/10.1021/acs.estlett.7b00035

40. Wu G, Qin W, Sun L et al (2019) Role of peroxymonosulfate on enhancing ozonation for micropollutant degradation: Performance evaluation, mechanism insight and kinetics study. Chem Eng J 360:. https://doi.org/10.1016/j.cej.2018.11.183

41. Xia D, He H, Liu H et al (2018) Persulfate-mediated catalytic and photocatalytic bacterial inactivation by magnetic natural ilmenite. Appl Catal B Environ 238:. https://doi.org/10.1016/j.apcatb.2018.07.003

42. Yang $Y$, Guo H, Zhang $Y$ et al (2016) Degradation of Bisphenol A Using Ozone/Persulfate Process: Kinetics and Mechanism. Water Air Soil Pollut 227:. https://doi.org/10.1007/s11270-016-2746-x 43. Yang Y, Jiang J, Lu X et al (2015) Production of Sulfate Radical and Hydroxyl Radical by Reaction of Ozone with Peroxymonosulfate: A Novel Advanced Oxidation Process. Environ Sci Technol 49:. https://doi.org/10.1021/es506362e

44. Zaied BK, Rashid M, Nasrullah M et al (2020) A comprehensive review on contaminants removal from pharmaceutical wastewater by electrocoagulation process. Sci. Total Environ. 726

45. Zhou Q, Li X, Wu S et al (2021) Enhanced Strategies for Antibiotic Removal from Swine Wastewater in Anaerobic Digestion. Trends Biotechnol. 39

\section{Figures}




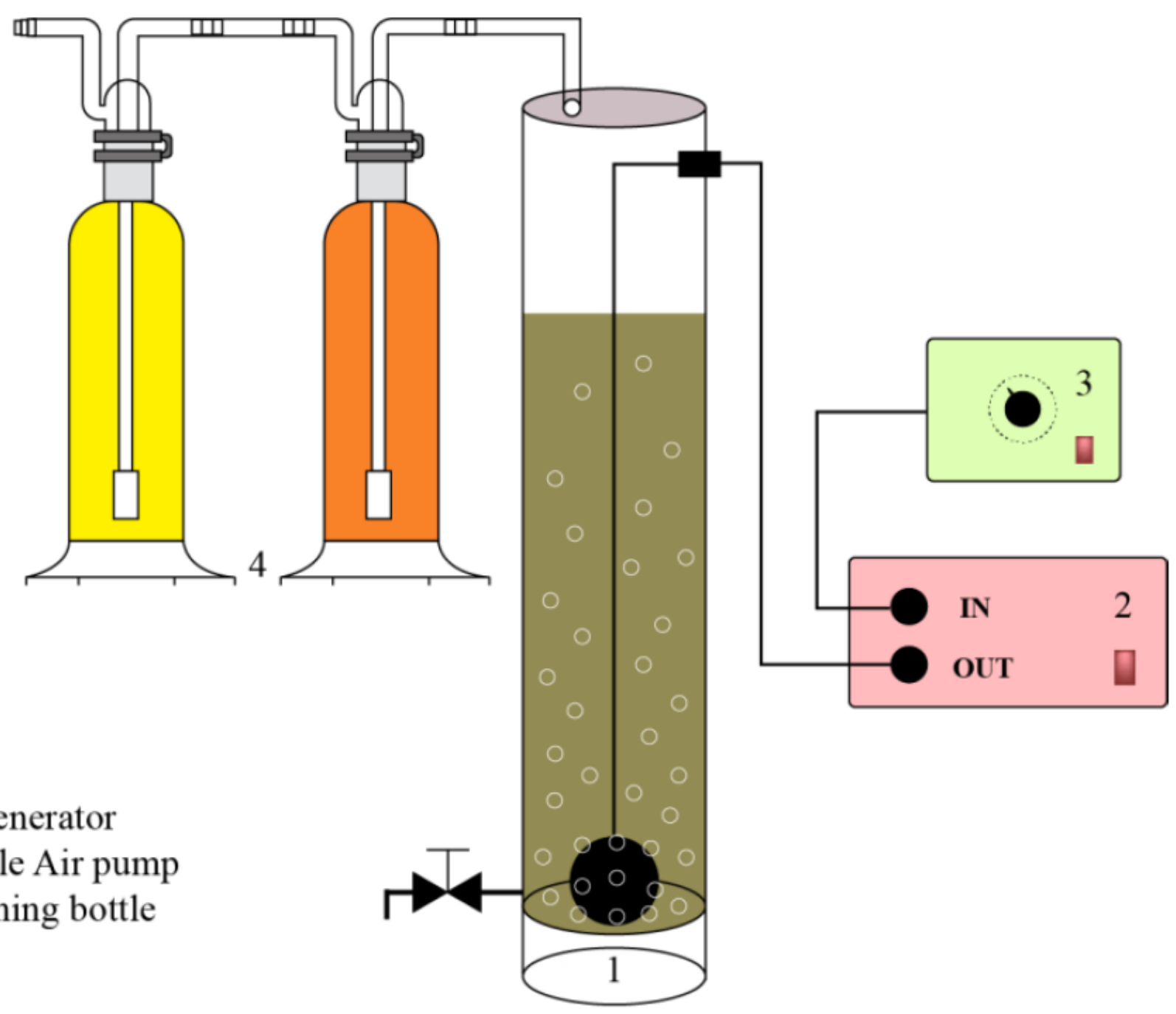

Figure 1

Schematics of the test setup 


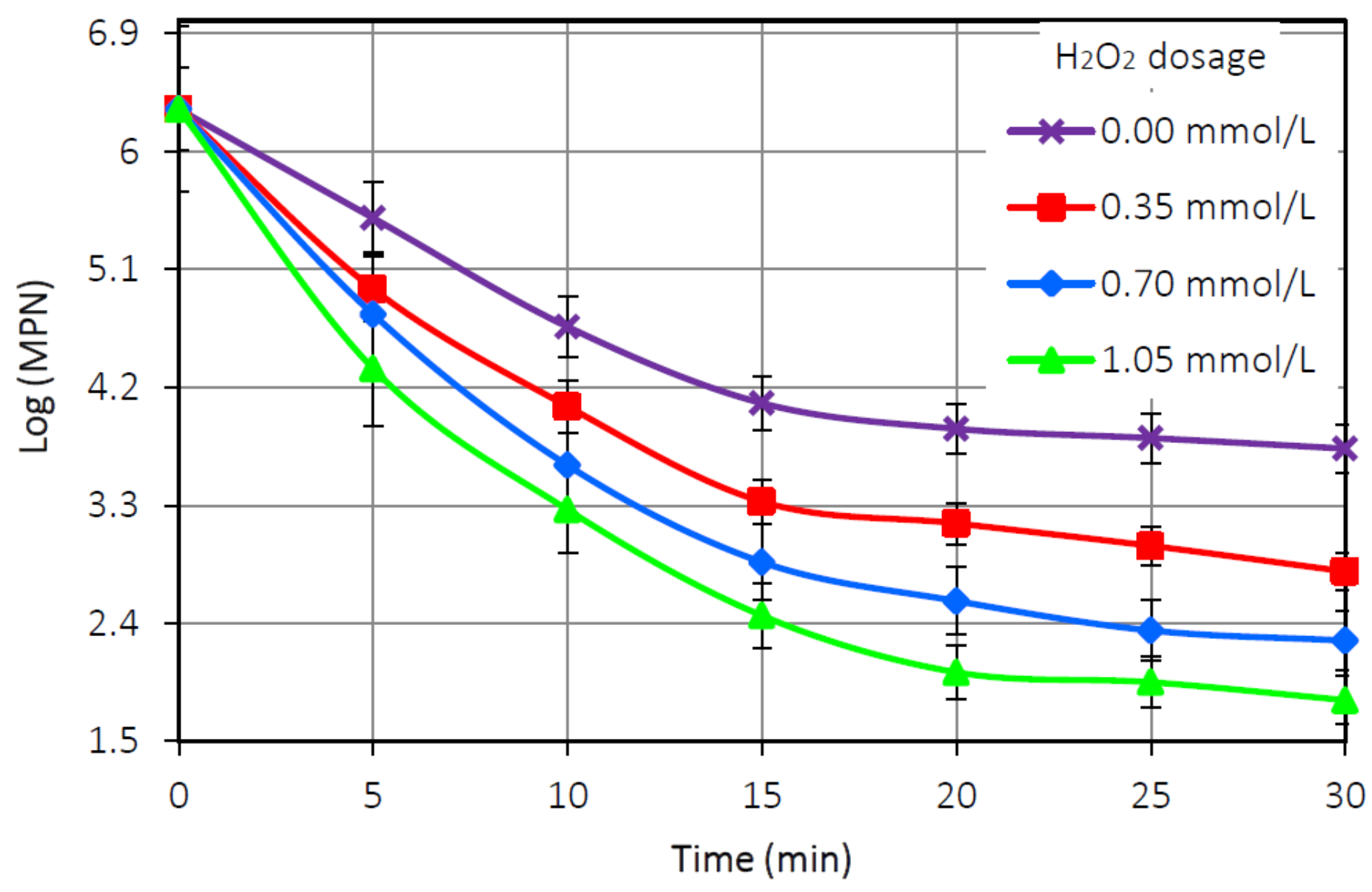

Figure 2

The effect of $\mathrm{H} 2 \mathrm{O} 2+\mathrm{O} 3$ method on the removal of total coliform in constant conditions of $\mathrm{pH}=6.9 \pm 0.1$ and ozone doze $=0.083 \mathrm{mmol} / \mathrm{L}$. 


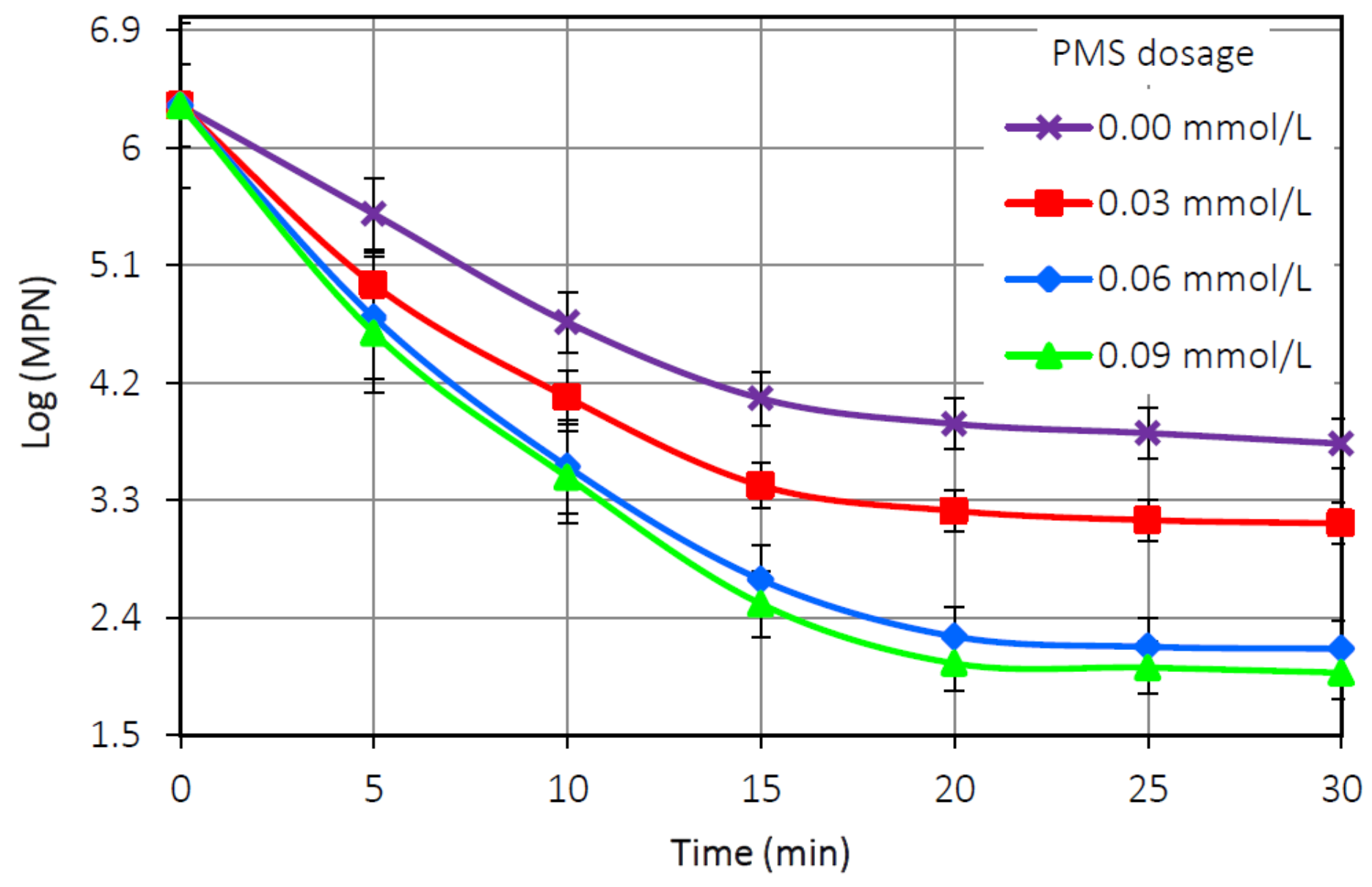

Figure 3

The effect of $\mathrm{PMS}+\mathrm{O} 3$ process on the removal of total coliform in constant conditions of $\mathrm{pH}=6.9 \pm 0.1$ and ozone doze $=0.083 \mathrm{mmol} / \mathrm{L}$. 


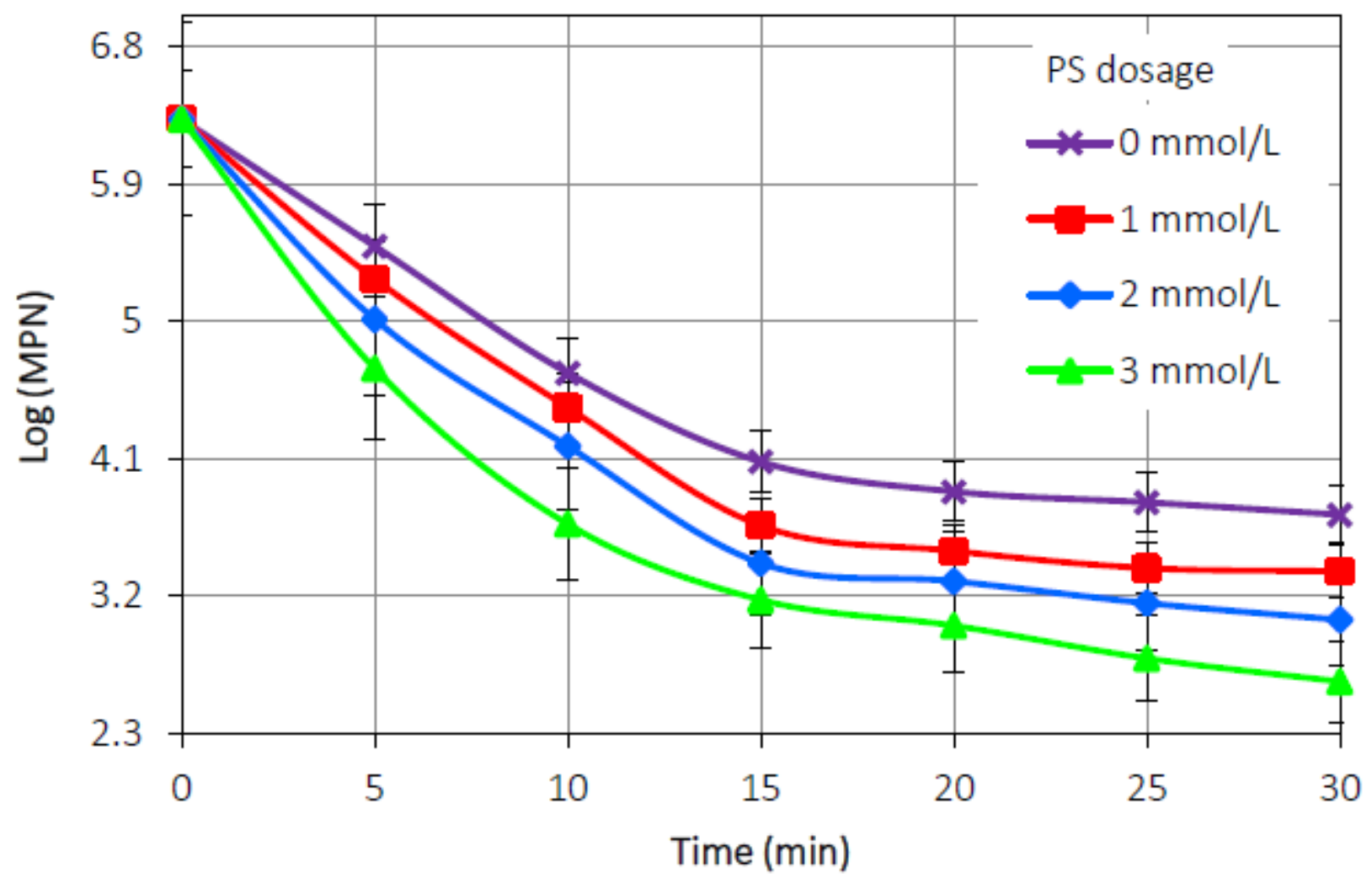

Figure 4

The effect of PS+03 method on the removal of total coliform in constant conditions of $\mathrm{pH}=6.9 \pm 0.1$ and ozone doze $=0.083 \mathrm{mmol} / \mathrm{L}$. 